University of Washington Tacoma

UW Tacoma Digital Commons

SIAS Faculty Publications

School of Interdisciplinary Arts and Sciences

2018

\title{
The Ecocritical Implications of Downing's Influence on Poe's Landscape Aesthetic
}

E.M. Bayer

University of Washington Tacoma, ebayer05@uw.edu

Follow this and additional works at: https://digitalcommons.tacoma.uw.edu/ias_pub

\section{Recommended Citation}

Bayer, E.M., "The Ecocritical Implications of Downing's Influence on Poe’s Landscape Aesthetic" (2018). SIAS Faculty Publications. 1038.

https://digitalcommons.tacoma.uw.edu/ias_pub/1038

This Article is brought to you for free and open access by the School of Interdisciplinary Arts and Sciences at UW Tacoma Digital Commons. It has been accepted for inclusion in SIAS Faculty Publications by an authorized administrator of UW Tacoma Digital Commons. 
The Ecocritical Implications of Downing's Influence on Poe's Landscape Aesthetic

Ellen M. Bayer

In an interview in the May 1912 issue of The Lotus Magazine, Nathan Barrett, a distinguished landscape architect, said of his field, “Read Poe’s 'Domain of Arnheim,' and you will understand what we are striving for.”1 Barrett helped found the American Society of Landscape Architects in 1899, served as the organization's president from 1902 to 1903, and influenced the field in the late-nineteenth and early twentieth century. ${ }^{2}$ That such a prominent practitioner would point to Poe's tale as representative of the aims of his own profession suggests that Poe had a sound grasp of the general theories and practices of landscape gardening. We can look to the many reviews of landscape gardening texts that appeared in the periodicals of Poe's time to see the widespread American interest in this field. No work was more widely read and influential at this time than Andrew Jackson Downing's 1841 Treatise on the Theory and Practice of Landscape Gardening. Poe knew this book through reading a review in Arcturus appearing in the same year and, as strong evidence suggests, through perusing Downing's tract firsthand sometime before 1843. Downing's Treatise and later works popularized a new aesthetic for the American landscape. His principles—most especially his belief that landscape gardening "affords pleasure to the mind, not only by the expressions of natural beauty which we discover in it, but by the more novel and choicer forms in which they are displayed, and by the tasteful art apparent in the arrangement” ${ }^{3}$ - correspond in significant ways with Poe's own aesthetic theories. In the 1847 tale, “The Domain of Arnheim” (an elaboration of the 1842 “The Landscape Garden”), Poe’s protagonist, Ellison, believes that the only "proper gratification" of the poetic sentiment is in the "creation of novel forms of Beauty" (M 3:1271). Ellison, echoing Downing, argues that the landscape architect must not imitate Nature but compose a landscape to produce a desired effect 
upon the viewer. Looking at the affinities between Downing's and Poe’s aesthetic principles, we may see that Downing's landscape gardening theory profoundly influenced Poe's later fiction and validated his belief in the powerful role of the artist in the creation of Beauty.

Poe's and Downing's works developed at a time when the importation of non-indigenous, ornamental plant species was in vogue, and, as biologist Richard Mack notes, the deliberate introduction of non-native flora in early America "caused enormous environmental and economic damage that ranges from threatening native biodiversity to changing the operation of major ecosystems. ${ }^{, 4}$ For Downing and other landscape architects, the introduction of exotic plant species served as the most immediate means for calling attention to man's hand in the landscape. ${ }^{5}$ The introduction, in turn, fueled the public demand for non-indigenous ornamentals, and the flora that Poe mentions in his landscape tales illustrate this trend. But these ornamentals came with serious costs. Two landscape tales, in particular, demonstrate the correlation between Poe's writing and the principles of landscape gardening popularized in his time: “The Domain of Arnheim” of 1847, and its “pendant” (M 3:1328), “Landor’s Cottage” of 1849. Situating Poe’s work in the context of landscape gardening —-first by establishing Downing's influence on Poe and then by examining the environmental impact of their idealized landscapes - we may see how both literary and horticultural texts echoed the broader culture’s demand for a composed American landscape without considering the consequences of putting these aesthetic theories into practice.

Some scholars have approached Poe's landscape tales as allegory. One common notion is that Poe seeks to create in prose a garden that rivals Eden but in which man can discern its beauty. ${ }^{6}$ Having fallen from grace, man is no longer capable of appreciating the art of creation in "pure" nature; it is only the artist's composed landscape that can reveal beauty. Another view is 
that Poe's gardens are surreal or artificial landscapes that range from "dreamscapes" to "prisons." ${ }^{7}$ While there is certainly merit in the Edenic or surreal/artificial interpretations of Poe's landscapes, most of these studies fail to consider his gardens as actual spaces.

Furthermore, some scholars have suggested that Poe's landscape tales were satire—a hoax or a lampooning of public taste ${ }^{8}$ — while, alternatively, others have produced compelling arguments that Poe's interest in the field was both genuine and deeply felt. ${ }^{9}$ Barbara Cantalupo concludes that, had his life not ended prematurely, Poe would have continued his landscape interest as a response both to public taste and his own personal appreciation for “"the beauty of the natural blue sky and the sunshiny earth. ${ }^{\prime 10}$ In light of Poe's letters to Sarah Helen Whitman ${ }^{11}$ and repeated revisions to and reprinting of his landscape tales, readers may find it difficult to read his interest in the landscape tradition as anything but sincere.

Scholars have studied Poe's responses to writings on landscape gardening, including his review of the works of landscape architect William Howitt ${ }^{12}$ and his incorporation of an 1841 Arcturus review of Downing's seminal work in “Arnheim."13 Robert D. Jacobs draws connections between Poe's literary criticism and the nineteenth-century principles of landscape gardening that he employs in his tales. ${ }^{14}$ While Jacobs acknowledges that Downing and a variety of British landscape architects possibly influenced Poe's work, Jacobs ultimately contends that it is more useful to understand Poe as drawing upon "a well established aesthetic tradition" instead of seeking "to establish any direct sources." ${ }^{15}$ Later, Catherine Rainwater offers a similar analysis, suggesting that Poe's reading of William Howitt's texts and subsequent review in Graham's Magazine in 1841 “could have more than adequately acquainted Poe with the theories and practices of the 'picturesque' in England,” and that this review was “augmented by his reading of Blackwood's Magazine, which throughout the 1830's contained numerous articles on 
the subject by such authorities as Gilpin and Archibald Alison.”16 Jacobs holds as common ground between Poe and landscape architects the shared belief in "the artist's role in adapting nature to the aesthetic requirements and emotional needs of humanity."17

Jeffrey A. Hess agrees with Jacobs that Poe could have gleaned some of the more general principles of landscape gardening from several authors, but Hess contends that it was Downing who proved the most influential. ${ }^{18}$ Hess provides persuasive evidence that Poe read Downing's Treatise, demonstrating the ways in which Poe's description of landscapes conforms to Downing's principles. ${ }^{19}$ For instance, Hess cites examples of Poe's use of specific trees that Downing classifies as "Picturesque" to create the picturesque elements of "Landor's Cottage" and of trees in Poe's work that Downing lists as generating a "softer" effect for the landscapes that correspond with the "Beautiful., ${ }^{20}$ George E. Mize comes to a similar conclusion as Hess, noting that while it is "conjectural" whether Poe read the works of prominent British landscape architects, "it is fairly certain he knew Andrew Jackson Downing’s Treatise."21 Joel R. Kehler expresses doubt “that Poe had any first-hand acquaintance with Downing's works prior to writing 'The Landscape Garden'” because Poe borrows from the Arcturus review and not the original text. ${ }^{22}$ Kehler goes on to concede that Poe probably “thumbed through” Downing's texts as "reference works" when he wrote "Landor’s Cottage," employing them as a guide for identifying trees with qualities that would correspond with his idealized American landscape. ${ }^{23}$ Departing from previous scholars, C.T. Walters suggests that Poe "meticulously read and adapted the most important treatise on landscape gardening of his age, Sir Uvedale Price's On the Picturesque. ${ }^{24}$ Walters argues that Poe paraphrases Price extensively, but this critic does not point to evidence of the paraphrase and misattributes Poe's discussion of the "natural" and "artificial" style of landscape gardening to Price instead of to the Arcturus review of Downing's 
Treatise that Poe clearly incorporates into “Arnheim.” Most recently, Cantalupo has added further evidence to demonstrate that Poe read Downing. Cantalupo suggests that Poe's numerous references to French landscape painter Claude Lorrain in comparison to his limited mention of American artists is perhaps due to the fact that "Downing repeatedly praises Claude" in his Treatise. Given that the Arcturus reviewer makes no mention of Claude, Cantalupo's reading reinforces the likelihood that Poe was not only familiar with, but also read first-hand, Downing's text. $^{25}$

\section{Downing's Influence on Poe}

George B. Tatum has called Andrew Jackson Downing (1815-1852) “the undisputed arbiter of American taste in matters relating to rural architecture and garden design," ${ }^{26}$ and, as such, Downing contributed to the upswing in the use of non-indigenous flora in the United States. Tatum notes that Downing was considered the "father of the public park in America," claiming that Americans today are the "beneficiaries" of a landscape tradition popularized by Downing. ${ }^{27}$ In Downing’s time, Catharine Maria Sedgwick observed that his books, “'are to be found everywhere. Nobody, whether he be rich or poor, builds a house or lays out a garden without consulting Downing’s works.", ${ }^{28}$ At the age of sixteen, Downing inherited his father’s successful nursery on the Hudson River, and he began publishing notices in horticultural periodicals a year later in 1832. He soon became an internationally renowned pomologist and shaped the advance of the fruit industry across New York State and into the American West. Downing went on to edit a prominent periodical in the field, The Horticulturalist, and published several texts on landscape gardens and architecture. He saw it as his personal responsibility to instill in Americans an appreciation for gardens, and he firmly believed that landscape "improvements" were accessible to all, no matter one’s socioeconomic class. ${ }^{29}$ 
Downing maintained that aesthetic taste was learned rather than linked to personal finances. His drive to democratize refined American culture appealed to an emerging middle class that welcomed his advice. First published in 1841, A Treatise on the Theory and Practice of Landscape Gardening went through four editions in Downing's lifetime, and its popularity inspired the development of several horticultural periodicals. ${ }^{30}$ Downing's influence was pervasive and had lasting effects on the composition of parks and rural residences long after his untimely death in the burning of a riverboat in 1852. In developing his own early practices, Downing looked to the books of two British landscape gardeners, Humphrey Repton and J. C. Loudon, "for more practical advice" than that offered by English aesthetic theorists. ${ }^{31}$ Both Repton and Loudon departed from tradition and embraced the use of exotic plant species and favored a more identifiable design in which a viewer can recognize the artist's hand. While Downing's landscape theories weren't wholly original, the American horticulturist adapted British models to the climates, soils, and landscapes of North America while packaging the British style in a manner that appealed to American sensibilities. In a gesture to posit the gardener as an artist, Downing titles himself a "rural architect" and also employs the term "the improver." ${ }^{32}$ Such diction further reinforces the sentiment that the landscape gardener composes landscapes and, as a result, improves upon their natural state. Poe shares this perspective, as placing a selection of his works into conversation with Downing’s Treatise will reveal.

We know definitively that Poe read a review of the Treatise in the June 1841 issue of Arcturus because he lifted parts of it and incorporated them into "The Landscape Garden" and its later revision, “The Domain of Arnheim.” Evidence suggests that Poe read Downing's Treatise sometime before the end of 1842, but it seems unlikely that he consulted it while composing “The Landscape Garden.” It is more probable that he developed this tale using general theories 
of landscape gardening that he had gleaned from a range of texts, including the Arcturus review. ${ }^{33}$ Poe incorporates the reviewer’s description of the "natural" and "artificial” styles of landscape gardening into his tale; Downing does not use this terminology in his Treatise but does discuss the sentiment behind these distinct styles. The anonymous Arcturus reviewer contends that, "The best proof of the value of Landscape Gardening is, the use it has been turned to by the poets.”34 He goes on to excerpt poems by Giles Fletcher and Andrew Marvell, and Poe includes part of Fletcher’s 1610 poem, “Christ’s Victorie on Earth,” as an epigraph to “The Landscape Garden” and "Arnheim.” Following the excerpts, the reviewer concludes that, "This is poetical landscape gardening; the art was not always so safe with its practical devotees,” suggesting that some practitioners of landscape gardening "abused" the art while the poets elevated it. ${ }^{35}$ Poe must have found "poetical landscape gardening" attractive, inspiring him to try his hand at demonstrating the power of his art while also appealing to popular taste for landscape gardening. Of Poe’s two landscape stories, “The Domain of Arnheim," with its articulation of aesthetic theories, is situated closer to the realm of the imagination, while "Landor's Cottage" is grounded in the concrete and presents a landscape garden such as one might encounter at an estate along the banks of the Hudson. ${ }^{36}$ Together, these tales represent both aspects of Downing's Treatisetheory and practice—and they model in fiction what Downing championed in life.

Hess has documented compelling evidence of Downing's direct influence on Poe's landscape tales, most especially “Landor’s Cottage,” and Kehler suggests that Poe didn’t read Downing's Treatise until sometime between 1845 and 1848- -if indeed it ever occurred at all. ${ }^{37}$ Cantalupo's reading of Poe's references to Claude Lorrain point to the Treatise's direct influence on “Arnheim.” An additional piece of evidence strongly suggests that Poe read Downing's text first-hand and that he did so earlier than Kehler supposed: Poe's use of the 
scientific name for the tulip tree, Liriodendron tulipifera. The Arcturus review reprints the Treatise's description of the tulip tree verbatim, with two significant exceptions: it omits Downing's two uses of the scientific name of this tree. ${ }^{38}$ In his definitive study of Poe's references to flora and fauna, William C. Woolfson lists four texts in which the tulip tree appears: "The Gold-Bug,” "The Elk,” an 1848 letter to Sarah Helen Whitman, and "Landor’s Cottage. ${ }^{39}$ With the exception of his letter to Whitman, Poe identifies the tulip tree using its scientific name, and he provides details that correspond with Downing's description of it.

Poe began composing "The Gold-Bug” in late 1841 and completed it in 1842. Given that we find Poe's first mention of the tulip tree in this tale, it seems probable that he read Downing's Treatise sometime between encountering the Arcturus review, which was published in June 1841, and publishing “The Gold Bug” in January 1843. In “The Gold-Bug,” the narrator describes "an enormously tall tulip-tree, which stood, with some eight or ten oaks, upon the level, and far surpassed them all, and all other trees which I had then ever seen, in the beauty of its foliage and form, in the wide spread of its branches, and in the general majesty of its appearance” (M 3:817-18); Downing also pays great attention to the tulip tree’s distinctive height, foliage, and form. ${ }^{40}$ Furthermore, Poe’s narrator notes that, "In youth, the tulip-tree, or Liriodendron Tulipferum, the most magnificent of American foresters, has a trunk peculiarly smooth, and often rises to a great height without lateral branches; but, in its riper age, the bark becomes gnarled and uneven, while many short limbs make their appearance on the stem” (M 3:818). This passage recalls Downing’s description of the tree’s “clean trunk, straight as a column" and his note that, "While the tree is less than a foot in diameter, the stem is extremely smooth, but when older, it becomes deeply furrowed, and is quite picturesque." ${ }^{41}$ 
In "Morning on the Wissahiccon” (“The Elk”), the narrator describes the banks of the river as "crowned at a greater elevation, with some of the most magnificent forest trees of America, among which stands conspicuous the liriodendron tulipiferum" (M 3:864). In a letter to Sarah Helen Whitman, dated October 18, 1848, Poe describes a dream garden he imagined for them to share which features "magnolias and tulip-trees" (M 3:1327; see also O 2:712), and in the sketch in which he elaborates on this idea, "Landor's Cottage," the tulip tree once again figures prominently. ${ }^{42}$ Here, the narrator notes that the tulip tree is "the pride of the valley, and beyond all question the most magnificent tree [he has] ever seen.... It was a triple-stemmed tulip tree - the Liriodendron Tulipiferum—one of the natural order of magnolias” (M 3:1332). As in "The Gold-Bug," Poe’s detailed description of the tree here echoes Downing's in its focus on the great height and distinctive trunk, foliage, and blooms of this species. While the review would provide Poe with Downing's general description of the tulip tree's qualities, Poe would have needed to consult an additional source to find its Latin name, since the Arcturus reviewer makes no mention of it. It seems highly probable, then, that Poe would turn to the original source for additional details about this tree. Downing's description of it as "decidedly the most stately tree in North America, ${ }^{43}$ and as a tree so majestic and revered that it was exported to Britain and Europe, where it was "esteemed as an ornamental tree of the first class," ${ }^{44}$ perhaps spoke to Poe's impulse to position the products of the United States — both literary and otherwise — as above and distinct from those across the Atlantic.

Beyond the botanical details that the Treatise provides, Downing's landscape aesthetics mirror Poe's theories on art that he outlines in his landscape tales, as well as in such essays as “The Philosophy of Composition,” "The Philosophy of Furniture,” and "The Poetic Principle.” The extent to which the two authors' perspectives overlap provides further evidence that Poe 
knew Downing's text beyond the Arcturus review. Downing's Treatise opens by proclaiming that modern practitioners "have raised Landscape Gardening to the rank it now occupies as an art of taste" and posits "the beau ideal in Landscape Gardening as a fine art, appears to us to be embraced in the creation of scenery expressive of a peculiar kind of beauty." ${ }^{45}$ Downing then suggests that landscape gardening differs from more utilitarian forms of horticulture in that it seeks to create an idealized landscape that does more than simply appeal to the palate, as with an orchard, or to the eye and nose, as with a flower garden. Instead, he champions "picturesque and beautiful imitations of nature, which join to fine forms, and elegance in arrangement, the higher beauty of sentiment or expression.”46 As we shall see, his artistic resonate with Poe’s philosophy.

Downing's Treatise promotes combining form and sentiment. His approach would have been attractive to Poe who, in “The Philosophy of Composition," states "that pleasure which is at once the most elevating, and the most pure, is, I believe, found in the contemplation of the beautiful” (L 2:63). Poe concludes that the contemplation of the beautiful will produce an “intense and pure elevation of soul” (L 2:63), and he recycles this sentence into his later essay, “The Poetic Principle.” Poe felt that the art of landscape gardening had a “wide field” for cultivating the "Poetic Sentiment” (L 2:184). Both Downing and Poe value producing a desired effect. In “The Philosophy of Composition,” Poe notes that he begins his creative process “with the consideration of an effect” (L 2:60). Later, in “The Poetic Principle,” he contends that we should determine the merit of a work of art not by the effort involved but "rather by the impression it makes, by the effect it produces” (L 2:180). Poe’s sentiment echoes Downing’s belief that "the most elevated kind of beauty in landscapes, of whatever description, is undoubtedly that of expression. And the highest imitative effects of the art, therefore, consist in 
arranging the materials, so as to create emotions of grace, elegance, picturesqueness, or grandeur, joined with unity, harmony, and variety, more distinct and more forcible than are suggested by natural scenery; producing by this means intellectual gratification, separate and distinct from that arising from the mere admiration of forms or materials employed." ${ }^{47}$

While one can find natural landscapes that embody the Beautiful, which are "characterized by simple and flowing forms," Downing is careful to note that the beauty of nature is something wholly different from the beauty of man's art. He posits "the recognition of art" as the first principle in landscape gardening while "fac-simile imitations of nature rank lowest” because they fail to produce "the pleasure experienced in the contemplation of art." 48 Unlike the "Classical" style of landscape gardening, which Downing found "mechanical" and lacking in theory, true "men of genius" could raise the profession to the rank of fine art by adding a tasteful variety of flora to the landscape in a unified and harmonious state. To accomplish this, the true artist cannot simply imitate nature; Downing holds this view so dear that he almost belabors the point in his Treatise. One passage here should suffice to convey this important distinction between art and imitation: "To copy the beauty of nature cannot be called being an artist in the highest sense of the word, as a mechanical talent only is requisite for this. The beautiful in art depends on ideas; and the true artist, therefore, must possess, together with the talent for technical execution, that genial power which revels freely in rich forms, and is capable of producing and animating them." ${ }^{49}$ In this view of the landscape garden, then, one cannot simply remove the unattractive elements and let the beauty of the landscape speak for itself. Furthermore, imitation of a wild landscape offers no opportunities for displaying artistic genius. To address this, Downing argues, "nothing can be more apparent, than the necessity of introducing largely, exotic ornamental trees, shrubs, and plants, instead of those of indigenous 
growth." " 50 A more striking and artistical effect," he continues, "will be produced by substituting for native trees and shrubs ... only rare foreign shrubs, vines, and aquatic plants" because "they will at once convey the idea of refined and elegant art." ${ }^{\text {51 }}$ Downing advises that "near the house, good taste will dictate" that the architect plant "exotic" flora while allowing the "commoner

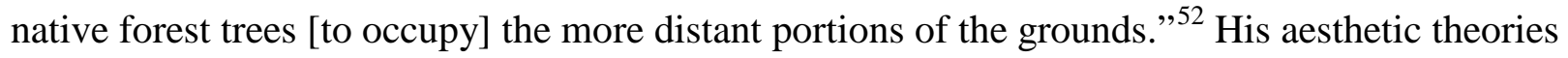
such as this helped to pave the way for the importation of non-indigenous ornamentals to "dwarf ... the number of new immigrant species in more utilitarian categories by” the mid-nineteenth century. ${ }^{53}$

Downing devotes several chapters of his Treatise to cataloging the most ideal trees, shrubs, vines, and other flora for consideration by "the improver," and he lists both native and non-indigenous species. What is striking about these chapters is that Downing's interest in the effect each specimen can produce drives his content. While he makes occasional mention of the utilitarian features of a tree, his overriding concern for each species is its aesthetic potential. For example, the landscape architect looking to convey a sense of "majesty" should consider the English Royal Oak, while the "pleasing harmony” of the White Ash’s autumn foliage makes it a "worthy" addition to any lawn—although its tendency to bloom late makes it ill suited for planting near the house ${ }^{54}$ He notes that some trees introduced from Europe and Asia might not be hardy enough for the soils and climate of North America and will require cultivation or a greenhouse; the adaptation of these trees to North America, in turn, calls for the use of additional resources, most significantly water and fuel. Aesthetic details shape Downing’s overview of each species, and he argues that the one thing the landscape architect must first know about trees is how to group them tastefully. Recommending the planting of trees in tasteful arrangements, the Treatise also encourages embellishing the trees. According to Downing, nothing makes a stand 
of native trees more picturesque than adding to it a mass of English Ivy, which, he claims, "is certainly one of the finest, if not the very finest climbing plant.”55

Ellison, the protagonist of “The Domain of Arnheim,” is artistically inclined and appreciates "the true character, the august aims, the supreme majesty and dignity of the poetic sentiment” (M 3:1271). Instead of turning to the musical, literary, or plastic arts, Ellison decides to use his fortune to cultivate an underappreciated "province" for nurturing the poetic sentiment: the landscape garden. He spends the remainder of his life seeking out the perfect location for his work and bringing his vision to life. Much of the tale is devoted to the narrator's description of the river voyage to Arnheim's secret location, concluding with only a very brief description of the garden itself. Ellison believes "the fullest, if not the sole proper satisfaction of [the poetic sentiment] ... lie[s] in the creation of novel forms of beauty” and claims that the landscape garden provides "the fairest field for the display of imagination in the endless combining of forms of novel beauty” (M 3:1271, 1272). Poe has Ellison quote directly from the Arcturus review of Downing's Treatise to explain the differences between what the reviewer terms the “natural” and the “artificial” styles of landscape gardening (M 3:1274-76; see also M 2:709-11).

Downing himself does not use these terms in this manner. Instead, he tends to use the terms “ancient” or “classical” and “modern” styles to differentiate between earlier geometrical compositions and contemporary models that draw upon principles of the beautiful and picturesque. The “natural” style entails removing unsightly “defects and incongruities” from a natural landscape, whereas the "artificial” style is achieved in a number of ways but always entails adding new elements to the landscape (M 3:1274-75). Rejecting the "natural style" of landscape gardening, Ellison claims, "the original beauty is never so great as that which may be introduced” (M 3:1275). Employing the natural style, one merely removes any defects from the 
scene instead of creating "special wonders," and Ellison dismisses a technique he deems "better suited to the groveling apprehension of the herd than to the fervid dreams of the man of genius" (M 3:1275).

The aspiration to “special wonders” aligns with Downing's belief that an artist's creation is superior to an untouched landscape. Ellison contends “many excesses and defects” exist in even "the most enchanting of natural landscapes" and that the composition of any landscape “will always be susceptible to improvement” (M 3:1272). Downing’s repeated reference to himself as an “improver” resonates with both Ellison's and Downing’s conviction that the work of the landscape architect improves upon “pure nature.” Ellison concludes, “in short, no position can be attained on the wide surface of the natural earth, from which an artistical eye, looking steadily, will not find matter of offence in what is termed the 'composition' of the landscape” (M 3:1272). While man cannot "imitate the colors of the tulip" (M 3:1273), he can arrange them in a more tasteful manner than one would find in the natural world. For Ellison, "in the most rugged of wildernesses" and "scenes of pure nature-there is apparent the art of a creator; yet this art is apparent to reflection only; in no respect has it the obvious force of a feeling” (M 3:1276). In this sense, the true poet can in some ways surpass divine creation by composing a landscape in which his art calls attention to itself and evokes recognition from the viewer. Poe's "Poetic Principle" also reflects the contempt Downing expressed toward creating a facsimile of nature. Poe argues that "mere repetition is not poetry" and that the man who simply sings of basic sensory details "has yet failed to prove his divine title" (L 2:183).

“Landor’s Cottage” was published in 1849 as a "Pendant” to “Arnheim” and puts into practice many of the theories outlined in Poe's earlier landscape tales. Here, the narrator makes a “pedestrian trip” through the Hudson River Valley of New York and in his wanderings stumbles 
upon a most magnificent landscape garden. “Landor’s Cottage” offers a more detailed description of the composed landscape than does "Arnheim," as the narrator marvels at the tasteful arrangement of various trees, shrubs, and other flora, and the eponymous cottage seems almost an afterthought. In "Landor's Cottage,” as the narrator pauses for half an hour "in bewildered admiration" to take in a landscape that an unseen hand has tastefully composed, he declares, "Here was art undoubtedly” (M 3:1330, 1329). He goes on to note, "an artist, and one with a most scrupulous eye for form, had superintended all these arrangements” and concludes, "It was a piece of 'composition,' in which the most fastidiously critical taste could scarcely have suggested an emendation” (M 3:1330). Like Ellison, who argued that "pure” landscapes offend the beholder with their disorderly composition and "will always be susceptible of improvement," the narrator of "Landor's Cottage" discovers an engineered landscape that he deems flawless in its design. He suggests that "it was not the amount but the character of the art which" gave him pause (M 3:1329), and this view recalls Downing’s argument that it is good taste, not wealth, that is essential in composing a beautiful landscape. Landor's arrangement integrates both indigenous and non-native flora and fauna, and the narrator remarks on the various species he encounters. Further echoing Downing and other prominent landscape architects, Landor chose species for the effect that they would produce on the viewer; given the narrator's sheer delight in the landscape, Landor appears to have succeeded in his objective.

The emphasis on good taste and order in the composed landscape links Poe's narrator to Downing beyond the strictly horticultural. David Wall notes that in the Treatise, Downing posits aesthetic taste "as a central component of American cultural identity." ${ }^{56}$ Downing and Poe worked in a time marked by an emergent nationalism in the antebellum United States, and Wall observes that the "shared experience of the landscape" helped to create "an ideology of all- 
inclusive Americanness. ${ }^{\text {} 57}$ Downing’s Treatise worked to popularize the myth of American unity by locating American patriotism in the arrangement of the natural world. In his Preface, Downing contends that "The love of country is inseparably connected with the love of home," and the practice of landscape gardening is paramount not only in providing aesthetic pleasure to the architect but also in "strengthening his patriotism and making him a better citizen." 58 Downing addressed the political, social, and cultural anxieties of his time by imposing structure and order on the landscape and, in so doing, sought "to create a uniquely American space.” For Downing, "the textual legitimization of his architectural space carries within it the legitimization of cultural, social, and ideological space." ${ }^{\text {59 }}$

As we shall see below, the construction of a "uniquely American space" did not necessitate the exclusive use of indigenous plant species. Downing, in fact, preferred the effect produced by introducing “foreign” plant species into the American landscape, and his Treatise openly acknowledges its debt to English landscape theories and practices. The influence of European examples posed no conflict to Downing's sense of nationalism; he borrowed from the longstanding British tradition and adapted it to "the difference in our soil and climate" as well as "our social and political position. ${ }^{60}$ Downing’s refusal to promote native plant species simply because they were American would have appealed to Poe in light of his fraught relationship with literary nationalism. It echoes Poe’s critique of Americans' "misapplied patriotism” in "liking a stupid book the better, because, sure enough, its stupidity is American” (H 8:277). As J. Gerald Kennedy notes, while "Poe resented British condescension toward American writing, he regarded provincialism and jingoism as even greater obstacles to national literary development." ${ }^{61}$ Poe draws a distinction between the political and the poetical: "That an American should confine himself to American themes, or even prefer them, is rather a political 
than a literary idea — and at best is a questionable point. We would do well to bear in mind that 'distance lends enchantment to the view.' Ceteris paribus, a foreign theme is, in a strictly literary sense, to be preferred” (P 2:508). Using landscape imagery to emphasize his point here, Poe’s argument complements Downing's privileging of taste and effect over blind nationalism. Despite Poe’s “American turn” in his short stories shortly after the publication of "The Landscape Garden” ${ }^{62}$ - he, like Downing, maintained artistic license in developing a national product that drew unapologetically from European traditions.

\section{Ecological Implications of Downing and Poe}

As a catalog of the species in both Ellison and Landor's gardens will prove, Poe's landscape architects, like Downing and other landscapists of his time, relied upon the introduction of nonindigenous plant species as a means for pushing their art beyond imitation. Poe identifies fifteen species of trees and nineteen plant species across both tales; this count does not include the unnamed species of foliage, flowers, shrubs, grasses, and trees to which Poe refers but which he

does not identify. ${ }^{63}$ Of the fifteen trees that we find in Poe’s landscapes, all appear in Downing's Treatise as being “worthy” of a place in one’s pleasure grounds for their ability to produce calculated effects. In most cases, Poe uses the common names of the plants and trees that populate his gardens; such names make it difficult to determine if some of the flora he mentions are native or introduced varieties (Fig. 1). ${ }^{64}$ 


\begin{tabular}{|c|c|c|}
\hline Native to U.S. & Introduced to U.S. & Native to U.S. and Abroad \\
\hline $\begin{array}{c}\text { Black Walnut } \\
\text { (M 3:1282; } \\
\text { 1332) }\end{array}$ & $\begin{array}{c}\text { Silver Willow } \\
\text { (M 3:1332) }\end{array}$ & Hickory (M 3:1332-33) \\
\hline $\begin{array}{c}\text { Sassafras } \\
\text { (M 3:1332) }\end{array}$ & $\begin{array}{c}\text { White Poplar } \\
\text { (M 3:1332) }\end{array}$ & Chestnut (M 3:1332) \\
\hline $\begin{array}{c}\text { Catalpa } \\
\text { (M 3:1332, } \\
\text { 1337) }\end{array}$ & Pear (M 3:1337) & Oak (M 3:1332) \\
\hline $\begin{array}{c}\text { Tulip Tree (M 3: } \\
\text { 1332-33, 1337) }\end{array}$ & & Elm (M 3:1332) \\
\hline & & Locust (M 3:1332, 1337) \\
\hline & & Linden (M 3:1332) \\
\hline & & Redbud (M 3:1332) \\
\hline
\end{tabular}

Fig. 1. Common names of trees as named by Poe with corresponding page numbers in "The Domain of Arnheim” and Landor's Cottage.”

Four trees are identifiable as native to the United States: the black walnut; sassafras; tulip tree; and catalpa (although the catalpa is native in the south and was naturalized further north only through cultivation). In fact, the black walnut and tulip trees were so popular with colonists that they exported them to Europe as early as the seventeenth century. ${ }^{65}$ Three species, the silver willow, white poplar, and pear, were introduced from Europe, and the remaining eight trees include species for which Downing promotes both native and non-native varieties. ${ }^{66}$

Turning to plant species, we find a high occurrence of non-indigenous ornamentals in Poe’s two tales. Of the twenty species named in “Arnheim” and "Landor's Cottage,” thirteen were introduced to the United States, one is native, and six are found both in North America and abroad (Fig. 2). ${ }^{67}$ 


\begin{tabular}{|c|c|c|}
\hline Native to U.S. & Introduced to U.S. & Native to U.S. and Abroad \\
\hline $\begin{array}{c}\text { Coral Honeysuckle } \\
\text { (M 3:1282) }\end{array}$ & $\begin{array}{c}\text { Grape vine } \\
\text { (M 3:1334, 1337) }\end{array}$ \\
\cline { 2 - 3 } & Poppy (M 3:1283) & Hydrangea (M 3:1334) \\
\hline & Eglantine (M 3:1282) & Violet (M 3:1283, 1340) \\
\hline & Hyacinth (M 3:1283) & Clematis (M 3:1282) \\
\hline & Tuberose (M 3:1283) & Water lily (M 3:1283) \\
\hline & Common Snowball (M 3:1334) & Geranium (M 3:1334, 1340) \\
\hline & Begonia (M 3:1337) & \\
\hline & Sweet Honeysuckle (M 3:1337) & \\
\hline & Tulip (M 3:1273, 1283) & \\
\hline & Syringa (M3 3:1334) & \\
\hline & Lily of the Valley (M 3:1273) & \\
\hline & Jasmine (M 3:1337) & \\
\hline & Grass/Turf (M 3:1281, 1329, & \\
& 1331, 1333, 1334, 1337) & \\
\hline
\end{tabular}

Fig. 2. Common names of plants as given by Poe in “The Domain of Arnheim” and "Landor's Cottage.”

Of the thirteen non-indigenous plant species in these two tales, at least two-eglantine, also known as sweet briar, and syringa, or lilac_-had been naturalized in the United States in Poe’s time. Eglantine is now considered "weedy and invasive” in some regions and is known for aggressively displacing native plant species. A third species, English Ivy, is invasive in some regions of the United States. ${ }^{68}$ The other non-indigenous species mentioned in the tales are such ubiquitous features in our gardens today that it is easy to lose sight of the fact that they are introduced species that rely on human cultivation. The six remaining plant species mentioned in Poe's tales include both native and non-indigenous varieties. It's important to keep these numbers in mind, since they point to the larger trend of the importation of non-indigenous plants for aesthetic purposes. While the precise number of naturalized flora in the United States is unknown, it definitely exceeds twenty-five hundred species; furthermore, researchers found that the majority of non-indigenous plants that naturalized before the twentieth century were 
deliberately introduced and cultivated by humans. ${ }^{69}$ Their studies reveal that, even though most of these species have not become invasive, some of them have nevertheless negatively impacted native ecosystems, and all of them have changed the face of the landscapes into which they were introduced.

Two examples of problematic introductions, ivy and turf grass—both of which Poe cites in his landscape tales-demonstrate some tangible consequences of nineteenth-century landscape practices. Downing's Treatise imports to North America a demand for the English lawn. In the first edition of this text, Downing positions the lawn as the canvas on which the architect will create his landscape; he offers innumerable references to the lawn as the element of the landscape into which the gardener introduces other flora. In later editions, Downing added a separate Appendix to address in more focused detail "the treatment of Lawns." In American Green: The Obsessive Quest for the Perfect Lawn, Ted Steinberg notes that "turf grass is not native to North America” and that "nearly all of the grass species found in America's yards today are immigrants from abroad,” including Kentucky Bluegrass. ${ }^{70}$ Downing’s recommended lawn seeds, Redtop and White Clover, were introduced in the United States during the seventeenth and eighteenth centuries. According to the United States Department of Agriculture (USDA), some states classify Redtop (Agrostis gigantea) as an invasive that can displace native flora, and it "is known to develop ergot which can lead to livestock poisoning." ${ }^{71}$ White clover (Trifolium repens) is found today in lawns across the United States. It, too, can become invasive, and by increasing nitrogen levels in soils, the introduction of white clover "can precipitate a host of other environmental changes, including a facilitation in the establishment of other alien species."72 Furthermore, turf grasses are not well adapted to North America’s climate. Downing was well aware of this fact and provides suggestions for maintaining a "velvet lawn" even in 
states that lack the "weeping skies" of England. ${ }^{73}$ Downing goes on to suggest that a lawn's "neatness" is maintained through careful mowing and that smoothing the ground with a heavy roller and correcting any irregularities before planting are key to producing the desired effect. The introduction of the lawn mower in the 1830s facilitated the democratization of the lawn in the United States, and Downing concludes this section with the hope "to see this indispensable feature in tasteful grounds becoming better understood and more universal.." ${ }^{, 74}$ We can look outside our windows today and see this wish fulfilled.

True to Downing's style, manicured lawns serve as the groundwork of Poe's landscape gardens. In fact, mentions of grass or turf appear in thirty-four of Poe's texts. ${ }^{75}$ During the boat's approach to the gates of Arnheim, a grand lawn rises smoothly from the riverbank. The narrator notes that the gentle slope is "obviously artificial," pointing to its composition by an artist (M 3:1281). Here, a description of the lawn as an "artificial element" should be understood as one of its key merits. The viewer feels the hand of the artist in the landscape, and its beauty and scale produce a desired effect on him: "Here the bank slopes upward from the stream in a very gentle ascent, forming a broad sward of grass of a texture resembling nothing so much as velvet, and of a brilliancy of green which would bear comparison with the tint of the purest emerald. This plateau varies in width from ten to three hundred yards" (M 3:1281). The narrator of "Landor's Cottage" is also smitten with the lawn he encounters and recognizes that, while it appears "more like Genoese velvet than anything else. It was grass, clearly—but grass such as we seldom see out of England—so short, so thick, so even, and so vivid in color” (M 3:1329). Here, as in Downing-who also describes turf as "velvet" ${ }^{, 6}$-we see that grass has shifted from its utilitarian role as forage to a largely aesthetic one. The narrator's description also points more directly to the fact that these are not native grasses; the narrator, in fact, praises the close-cropped 
grasses for being of foreign origin.

As he approaches the cottage, the narrator finds that "[t]he expanse of the green turf was relieved, here and there, by an occasional showy shrub, such as the hydrangea, or the common snow-ball, or the aromatic seringa” (M 3:1334), as well as geraniums-two of these shrubs are non-native, and the other two include both native and non-native varieties. ${ }^{77}$ What is most striking here is that the narrator observes "geraniums blossoming gorgeously in great varieties... . [growing] in pots which were carefully buried in the soil, so as to give the plants the appearance of being indigenous” (M 3:1334). Poe's hiding the exotic nature of the plants seems to work against Downing's call to emphasize the exotic nature of certain species of flora, but Poe’s narrator is nevertheless aware of the architect's aim to produce a desired effect and recognizes that these particular geraniums are not native to the region. The narrator celebrates the artificiality of the composition, which highlights the art and design of the landscape. The potential impact of introducing the "foreign" species into the local ecosystem does not concern Poe here; he approaches this practice from a theoretical perspective and values the plant solely for its role in composing that landscape. This corner of the lawn is also "exquisitely spotted with sheep” (M 3:1334). We can add these sheep to the list of introduced species, and, as noted earlier, colonists imported English grasses and clovers in order to feed the sheep and their fellow imported ruminants. The seed stock for the grasses and clovers came from abroad and contained (sometimes deliberately) other contaminates that in some cases naturalized. ${ }^{78}$

Downing praises English Ivy (Hedera helix) throughout his Treatise, devoting a significant part of his chapter on "Vines and Climbing Plants" to outline the picturesque effects that this plant can produce in gardens, forests, and architecture. English ivy appears in nine of Poe's texts. ${ }^{79}$ English Ivy's foliage is evergreen, which, for Downing, "enhances its value ten- 
fold." ${ }^{80}$ Downing makes briefer mention of Virginia creeper (Ampelopsis hederacea), which is also known as American Ivy. American Ivy isn’t evergreen, and Downing admires its showy fall colors as the one quality with which the native plant outshines the introduced species. It is unclear which species winds its way into Poe’s tales; regardless of whether it is the English or American variety, both species are known for crowding out other plants, killing host forest trees, and causing structural damage to buildings. ${ }^{81}$ The wall atop the plateau that lines the riverbanks in "Arnheim" "is profusely overhung and overspread with the ivy," and the narrator's view of the horizon “is impeded by an impenetrable screen of foliage” (M 3:1281-82). The diction here is telling and paints an image of the ivy overtaking its environment.

The narrator appears to see the ivy in a different light, suggesting that it adds to the picturesque charm of the scene. His view further evidences Poe’s interest in landscapes from a theoretical rather than practical perspective. We find a similar image in “Landor’s Cottage,” when the narrator describes the cliffs on which "grew ivy in great profusion-so that only here and there could even a glimpse of the naked rock be obtained” (M 3:1334). Downing suggests that while ivy may cause structural damage to a wooden house, it strengthens stone buildings and walls, holding "both stone and mortar together like a coat of cement," and the foliage "with which it covers the surface, excludes stormy weather, and has therefore a tendency to preserve the walls.” Furthermore, Downing notes that "bare walls and fences may thus be clothed with verdure and beauty equal to the living hedge.” Poe’s narrator, then, maintains a perspective that complements Downing's call to introduce masses of English ivy into the landscape. Downing goes so far as to lament that, despite the fact that "ivy is not a native of America ... [it] is by no means a very common plant in our gardens, though we know of no apology for the apparent neglect of so beautiful a climber." ${ }^{22}$ This sentiment suggests that, because English ivy was not 
widespread at this time, neither Downing nor Poe would have known of the extensive ecological damage this species could wreak upon American ecosystems. Today, English Ivy has spread throughout much of the United States, and many nurseries continue to sell it as a lowmaintenance, inexpensive ground cover. Its reputation for escaping from cultivation is well earned. It is notorious for spreading quickly, outcompeting native flora, and killing its host trees. The spread of English Ivy is of particular concern in the Pacific Northwest, and Oregon now bans its sale, and Washington lists it as a noxious weed. ${ }^{83}$ The fact that gardeners nevertheless still invite it into their yards speaks to the strong grip that aesthetic tastes continue to hold on us today.

\section{Conclusion}

Both Poe and Downing describe additional methods of "improving" landscapes that have environmental consequences—-such as the diversion and damming of streams, the sculpting of artificial lakes and banks, and the construction of roads and paths—-but even without delving into these areas, we can see how the introduction of plant species for purely aesthetic reasons can impact and alter a landscape. Poe's and Downing's landscape theories and practices have large environmental implications. There is no evidence to suggest that either Downing or Poe considered, or were concerned with, the ecological impact of introducing non-indigenous species. Frances F. Dunwell notes that, “Downing felt torn between admiration for America's frontier spirit and concern for the destruction of nature that went with it”; he nevertheless traveled the lengths of the Hudson River selling "exotic" species such as "night-smelling jasmine and Scotch rose" to the estates that lined its banks. ${ }^{84}$ Both of these plant species are now classified as invasive in the United States and elsewhere. ${ }^{85}$ Botanists in Downing's time both understood and observed the far-reaching effects of the introduction of non-indigenous flora, but 
their research tended to focus on the problems posed by invasive species to agriculture. ${ }^{86}$ In the mid-nineteenth century, though, the private sector was the largest importer of non-native plants, and ornamentals “became the largest single functional category of imported species.” ${ }^{\text {87 }}$ Perhaps Downing did not fully grasp the ecological implications of his theories and practices, but, given his pervasive influence in shaping American landscapes, both public and private, his work clearly contributed to the popularization of introducing non-indigenous species, many of which have since naturalized or become invasive. The aesthetic theories that he privileges in "Arnheim” and “Landor’s Cottage” express both his own and the general public's preferences for shaping the land. Such preferences maintain a strong influence on the landscape practices of our contemporary world and validate our own tastes. Poe’s landscape tales illustrate his theoretical admiration of “novel forms of Beauty," but others have put theory into practice—-in Poe's time and in our own—sometimes with disastrous environmental costs.

Much remains in Poe’s work to explore through the lens of environmental criticism. In addition to “Arnheim” and “Landor’s Cottage,” works such as The Journal of Julius Rodman, “The Island of the Fay,” "Eleonora,” and “Morning on the Wissahiccon” offer pastoral and western landscapes for consideration as ecological environments. Beyond these more picturesque tales, Poe’s gothic and sublime landscapes, as well as his built environments, could also benefit from environmental analyses, opening new avenues for understanding the function of such settings in Poe’s fiction. As postcolonial approaches to environmental criticism gain momentum, Poe studies might also consider the intersections of empire and ecology in his landscape aesthetics. Interdisciplinary approaches to Poe's work will continue to offer insights into the powerful influence of literary texts on American culture. 


\section{Notes}

${ }^{1}$ Nathan Barrett, “A Poet’s Vision of Landscape Architecture: Edgar Allan Poe’s ‘The Domain of Arnheim,”” The Lotus Magazine 3, no. 8 (1912): 242-50.

${ }^{2}$ For more on The American Society of Landscape Architects (ASLA), see http://www.asla.org/default.aspx.

${ }^{3}$ Andrew Jackson Downing, A Treatise on the Theory and Practice of Landscape Gardening, Adapted to North America (New York: Wiley and Putnam, 1841), 34. Web.

${ }^{4}$ Richard Mack, “Plant Naturalizations and Invasions in the Eastern United States: 1634-1860,” Annals of the Missouri Botanical Garden 90, no. 1 (2003): 77-90.

${ }^{5}$ A range of terms may be used to describe plants that are not native to a particular region: including “foreign,” “exotic,” “alien,” “non-native,” “introduced,” and “non-indigenous.” These identifiers are synonymous and come loaded with larger socio-political implications. Downing primarily refers to "introduced” species as “foreign” and “exotic,” and these terms, along with “alien,” appear in popular publications today. Modern academic literature in ecology classifies these species as “introduced,” “non-indigenous,” or “non-native,” and I use these terms here interchangeably. An “adventive” species has been introduced to a new region but typically requires human cultivation in order to reproduce it. An "introduced species" that has become established, is self-sustaining, and can reproduce without human intervention is termed “naturalized.” When an “introduced species” becomes prolific, spreads, and causes economic or environmental damage, it is then identified as “invasive.” There is often debate about whether a particular species has become “invasive,” and the same species can be categorized as "invasive” or "naturalized" depending on region. Finally, ornamentals include species introduced solely for their aesthetic qualities and can be “indigenous” or “non-native.” See Richard N. Mack and 
Marianne Erneberg, “The United States Naturalized Flora: Largely the Product of Deliberate Introductions,” Annals of the Missouri Botanical Garden 89, no. 2 (2002): 176-89.

${ }^{6}$ For sources that examine Poe’s gardens as Edenic, see the following: Robert D. Jacobs, “Poe’s Earthly Paradise,” American Quarterly 12, no. 3 (1960): 404-13; Jeffrey A. Hess, “Sources and Aesthetics of Poe’s Landscape Fiction,” American Quarterly 22, no. 2 (1970): 177-89; and Kent Ljungquist, The Grand and The Fair: Poe’s Landscape Aesthetics and Pictorial Techniques (Potomac, Md.: Scripta Humanistica, 1984).

${ }^{7}$ For sources that examine Poe’s gardens as surreal or artificial, see the following: Sharon Furrow, "Psyche and Setting: Poe’s Picturesque Landscapes,” Criticism 15, no. 1 (1973): 16-27; Catherine Rainwater, “Poe’s Landscape Tales and the 'Picturesque’ Tradition,” The Southern Literary Journal 16, no. 2 (1984): 30-43; and Joan Dayan, Fables of Mind: An Inquiry into Poe’s Fiction (Oxford: Oxford University Press, 1987). See also the sources listed in Endnote 9 below. ${ }^{8}$ See Rainwater, “Poe’s Landscape Tales,” and Beth L. Lueck, American Writers and the Picturesque Tour: The Search for National Identity, 1790-1860 (New York: Garland, 1997). ${ }^{9}$ See Jules Zanger, “Poe’s American Garden: 'The Domain of Arnheim,'” ATQ no. 50 (1981): 93-103 and Barbara Cantalupo, Poe and the Visual Arts (University Park: The Pennsylvania State University Press, 2014).

${ }^{10}$ Cantalupo, 1, 159.

${ }^{11}$ Mabbott notes that in an October 18, 1848, letter to Helen Whitman, Poe writes, “Meantime, I enclose ... 'The Domain of Arnheim' which happens to be at hand, and which, moreover, expresses much of my soul.’” Mabbott also suggests that Poe’s “idea for ['Landor’s Cottage’] began to take shape” in this letter, as Poe imagines here a beautifully landscaped garden and cottage (M 3:1266, 1326). For the original letter, see (O 2:712). 
${ }^{12}$ Poe reviewed two works by English landscape architect William Howitt in 1841 for Graham's Magazine: the 1838 The Rural Life of England and the 1841 Visits to Remarkable Places.

${ }^{13}$ For sources that consider the possible influence of actual gardens on Poe's landscape aesthetic, see the following: George E. Mize, “The Matter of Taste in Poe’s 'Domain of Arnheim' and 'Landor’s Cottage,’” Connecticut Review 6, no. 1 (1972): 93-99; Takayuki Tatsumi, “Poe’s Idea of Art: A Study of 'The Domain of Arnheim,'” Sophia English Studies 5 (1980): 45-61. 14 Jacobs, 405.

${ }^{15}$ Ibid., 406. Kent Ljungquist reaches the same conclusion: “There is little external evidence that Poe had detailed knowledge of particular British aestheticians of the picturesque. ... However, there is considerable reason to believe that he had general familiarity with the movement. For example, in 'The Domain of Arnheim,' the narrator, speaking of the improvements on nature that can be achieved by landscape gardening, uses the terminology of the aesthetic triad [the beautiful, the sublime, and the picturesque] that dominated so many eighteenth-century treatises.” Ljungquist, 36.

${ }^{16}$ Rainwater, 32.

${ }^{17}$ Jacobs, 404.

${ }^{18}$ Hess, 179.

${ }^{19}$ While Hess provides the most convincing arguments that Poe read Downing's work, he misreads both Poe's response to the Treatise as well as Downing’s philosophy. Hess claims that Downing privileged the "natural style” of landscape gardening and, as a proponent of the “artificial style,” Poe used his tales as a means for challenging Downing’s aesthetic. See below for a fuller discussion of these two gardening styles and an explanation of how Downing and Poe clearly both privilege the "artificial style.” 
${ }^{20}$ Ibid., 185. Also, see pages 186-87 for additional examples.

${ }^{21}$ Mize, 94. Like Hess, Mize also points to textual evidence to reinforce his contention of Downing's direct influence on Poe's tales; see page 95 in particular.

${ }^{22}$ Joel R. Kehler, “New Light on the Genesis and Progress of Poe’s Landscape Fiction, “American Literature 47, no. 2 (1975): 173, 176.

${ }^{23}$ Ibid., 179.

${ }^{24}$ C. T. Walters, “'The Philosophy of Furniture’ and Poe's Aesthetics of Fictional Design,” The Edgar Allan Poe Review 5, no. 1 (2004): 72.

${ }^{25}$ Cantalupo, 47. Cantalupo also observes that Poe's incorporation of the Arcturus review into “The Landscape Garden” demonstrates his familiarity with Downing and his general theories. As I discuss later, I date Poe’s reading of Downing's Treatise to sometime between June 1841 and the end of 1842 .

${ }^{26}$ George Tatum, “Introduction” in Landscape Gardening and Rural Architecture, by Andrew Jackson Downing (New York: Dover Publications, 1991), v.

${ }^{27}$ Ibid., vi.

${ }^{28}$ Frances F. Dunwell, The Hudson: America's River (New York: Columbia University Press, 2008), 155.

${ }^{29}$ For example, Downing describes the accessibility of landscape practices to residents ranging from the owner of a country estate to the tenant of "the humblest cottage by the way side." Downing, Treatise, iv.

30 The complete title of Downing's work is as follows: A treatise on the theory and practice of Landscape Gardening, adapted to North America; with a view to the improvement of country 
residences. Comprising historical notices and general principles of the art, directions for laying out grounds and arranging plantations, the description and cultivation of hardy trees, decorative accompaniments to the house and grounds, the formation of pieces of artificial water, flower gardens, etc., with remarks on rural architecture, illustrated by engravings. The Dover Edition, cited below, shortens the title to Landscape Gardening and Rural Architecture.

${ }^{31}$ See Tatum, “Introduction,” xiii.

${ }^{32}$ Ibid., xix. Note that the terms “landscape gardener” and “landscape architect” are synonymous, and I use them interchangeably here. The biographical information on Andrew Jackson Downing here comes from Tatum, “Introduction,” v-xix, and David Schuyler, Apostle of Taste: Andrew Jackson Downing 1815-1852 (Baltimore: The Johns Hopkins University Press, 1996), 1-8.

${ }^{33}$ See sources listed in notes 13-25 for suggestions as to texts/concepts that Poe was familiar with at this time.

34 “American Landscape Gardening,” Arcturus: A Journal of Books and Opinion 2, no. 7 (1841): 36.

35 Ibid., 38.

${ }^{36}$ Dunwell notes that “nowhere are [Downing's] principles and philosophy of landscaping and architecture more evident than in the Hudson Valley, where nearly every nineteenth-century style he popularized can be found” (161).

${ }^{37}$ See Hess, 184-87 and Kehler, 179.

${ }^{38}$ Mabbott observes that "The name used by botanists is Liriodendron tulipifera, but Poe changed the adjective to agree with dendron, which is neuter. There are no specimens on or near Sullivan’s Island.” While he points out that "Poe gives the name in correct Latin,” Mabbott does 
not note that the Arcturus review omits this detail from Downing's description of the tree (M $3: 1341)$.

${ }^{39}$ William C. Woolfson, Flora and Fauna in the Works of Edgar Allan Poe: An Annotated Index (New York: Senda Nueva De Ediciones, 1992). Woolfson gives the title as “The Elk” instead of "Morning on the Wissahiccon.”

${ }^{40}$ See Downing, Treatise, 197-200.

${ }^{41}$ Downing, Treatise, 198-99.

${ }^{42}$ In his introduction to “Landor’s Cottage,” Mabbott notes that “From its setting [Poe] excluded magnolia trees, none of which grew north of Philadelphia in his day” (M 3:1327).

${ }^{43}$ Downing, Treatise, 198.

${ }^{44}$ Ibid., 199.

45 Ibid., 29, 34.

${ }^{46}$ Ibid., 39.

47 Ibid., 34.

${ }^{48}$ Ibid., 43, 38-9.

49 Ibid., 35.

50 Ibid.

${ }^{51}$ Ibid., 290.

52 Ibid., 55.

${ }^{53}$ Mack, 88.

${ }^{54}$ Downing, Treatise, 103, 114-15.

${ }^{55}$ Ibid., 245. 
${ }^{56}$ David Wall, “Andrew Jackson Downing and the Tyranny of Taste,” American Nineteenth Century History 8, no. 2 (2007): 199.

${ }^{57}$ Ibid., 195.

${ }^{58}$ Downing, Treatise, iii.

${ }^{59}$ Wall, 195.

${ }^{60}$ Downing, Treatise, i.

${ }^{61}$ J. Gerald Kennedy, “‘A Mania for Composition’: Poe’s Annus Mirabilis and the Violence of Nation-Building,” American Literary History 17, no. 1 (2005): 6.

${ }^{62}$ See J. Gerald Kennedy’s “Poe’s ‘American Turn’: Opposing Nationalism, Appeasing the Nationalists” in Poe Writing/Writing Poe, ed. Richard Kopley and Jana Argersinger. (New York: AMS Press, 2013), 99-126.

${ }^{63}$ Not included in this count are plant species that Poe names as reference points but that don't actually appear in the landscapes. For instance, Poe mentions cypresses in "Landor’s Cottage” but only as an example of a tree that is almost as beautiful as the tulip tree. (M 3:1332.)

${ }^{64}$ Further research into Poe’s sources, both literary and actual gardens he may have known, could possibly help to verify the specific species referenced in the tales.

${ }^{65}$ Andrew Jackson Downing, Landscape Gardening and Rural Architecture (1865; New York: Dover Publications, 1991), 228.

${ }^{66}$ Again, without having the scientific names, we cannot definitively determine whether the remaining eight species that Poe’s narrators name are “introduced” or “native.”

${ }^{67}$ As with the tree species noted above, further research may illuminate whether the plants in this third and final category were "introduced” or "native” species. 
${ }^{68}$ See Mack and Erneberg, 180; 186; P.L.S. Pavek, "Plant guide for sweetbriar rose (Rosa rubiginosa L.),” 2012, 1-2, http://www.nrcs.usda.gov/Internet/FSE_PLANTMATERIALS/publications/wapmcpg11563.pdf; and Melissa A. Waggy, “Hedera helix,” 2015, http://www.fs.fed.us/database/feis/plants/vine/hedhel/all.html.

${ }^{69}$ Mack, 77, and Mack and Erneberg, 178, 179.

${ }^{70}$ Ted Steinberg, American Green: The Obsessive Quest for the Perfect Lawn (New York: W.W. Norton, 2007), 11.

${ }^{71}$ Derek Tilley, Dan Ogle, and Loren St. John, "Plant Guide for Redtop (Agrostis gigantean),” 2010, 3, http://plants.usda.gov/plantguide/pdf/pg_aggi2.pdf.

${ }^{72}$ Mack, 84.

${ }^{73}$ Downing, Landscape Gardening, 421.

${ }^{74}$ Ibid., 424.

${ }^{75}$ See Woolfson, 27, 50.

${ }^{76}$ Downing, Treatise, 18.

${ }^{77}$ See Fig. 2 above.

${ }^{78}$ Mack and Erneberg, 183.

${ }^{79}$ See Woolfson, 30.

${ }^{80}$ Downing, Treatise, 245.

${ }^{81}$ See Kellie King and James Henson, "Virginia Creeper,” http://plants.usda.gov/plantguide/pdf/pg_paqu2.pdf and Melissa A. Waggy, "Hedera helix," 2015, http://www.fs.fed.us/database/feis/plants/vine/hedhel/all.html

${ }^{82}$ Downing, Treatise, 246, 248, 247. 
${ }^{83}$ While English Ivy is considered invasive in the Pacific Northwest, in other regions it is considered naturalized. See, for example, the Washington State Noxious Weed Control Board's website, http://www.nwcb.wa.gov/detail.asp?weed=59, or the Oregon State University Extension Service website, http://extension.oregonstate.edu/gardening/node/948.

${ }^{84}$ Dunwell, 147.

85 “Invasive Plant Atlas of The United States,” 2010

http://www.invasiveplantatlas.org/distribution.html

${ }^{86}$ For example, in 1832, Lewis David de Schweinitz’s study of naturalized flora provided one of two "extraordinarily valuable benchmark accounts that deal specifically with the scope and status of non-indigenous species along the East Coast of the U.S.” The second account, produced by William Darlington in 1859, records the impact of non-indigenous species, but "was explicitly concerned with those species that were troublesome in agriculture.” See Mack, "Naturalizations and Invasions,” 86.

${ }^{87}$ Ibid., 80, 85. 